\section{IJ§ER}

ISSN: 2149-5939
International Journal of Social Sciences and Education Research

Online, http://dergipark.gov.tr/ijsser

Volume: 4(2), 2018

\title{
A systematic review of flipped classroom studies in Turkish education
}

\author{
Nurhan Tütüncü ${ }^{1} \quad$ Meral Aksu $^{2}$
}

Received Date: 14 / 02 / 2018

Accepted Date: 30 / 03 / 2018

\section{Abstract}

The purpose of this systematic review is to investigate the flipped classroom (FC) studies conducted in Turkey. The review reported on 38 studies- 27 research articles, 9 master's theses and 2 PhD dissertations- published from 2014 till 2017 in ERIC, Science Direct, Web of Science, ULAKBIM, EBSCOhost, JSTOR, CoHE, and DOAJ. The results showed FC related studies conducted in Turkey have four major focuses: achievement, attitudes, motivation and perspectives of the students in FC and traditional classrooms. As a results, the majority of the studies concluded that students taught in FC increased their achievement, are reported to be more motivated, and developed positive attitudes.

Keywords: Flipped classroom, Systematic review, Turkish education

\section{Introduction}

In order to keep up with the technology, educational strategies and methods also need to be revised and updated. There have been important changes in education system up to know such as use of different methods or change in the roles of teachers and students (Yildirım \& Kıray, 2016). According to Bishop and Verleger (2013), a model enabling students to reach the contents individually, to have active roles and to follow the content in accordance with their individual interest areas is initially preferred with the contribution of rapid changes in technology today since the generation, today, called as millennial generation (Wilson \&Gerber, 2008) or digital natives (Prensky, 2001) has more access to technology and information easily, which makes the traditional teaching models insufficient to meet students' expectations (Y1ldırım \& K1ray, 2016). In this sense, instead of traditional teaching methods, it is suggested to create learning environments including active learning strategies for problem solving (Barak, Harward, Kocur \& Lerman, 2007; Marbach-Ad \& Sokolove, 2002). Therefore, it became a necessity to create learning environments for individuals to make them question, use technology effectively and develop higher-order thinking skills (Azemi, 2013; Bishop \&Verleger, 2013; Tezci \& Perkmen, 2013). In recent years, the learning concept expressed in various ways such as "Flipped Classroom" and "Inverted Classroom" in international studies and "Ters-Yüz Sınıf Modeli" "Çevrilmiş Öğrenme Modeli" or "Evde Ders Okulda Ödev" (in Turkish, partly surpass the borders built by learning environments (as cited in Y1ldırım \& Kıray, 2016). Although the idea of flipped classroom is not new (Davies, Dean and Ball, 2013) and it has been in existence within the broader educational sphere for a number of years (Tan, Yue \& Fu, 2017); the modern flipped classroom began in 2007 in a high school chemistry course in Colorado (as cited in Tan et al., 2017). Jonathon Bergmann and Sams (2012) recorded videos and screen casting in order to compensate for the lessons their students

${ }^{1}$ TOBB University of Economics and Technology, Ankara, Turkey, ntutuncu@etu.edu.tr

${ }^{2}$ Middle East Technical University, Ankara, Turkey, aksume@metu.edu.tr 
Tütüncü, N. Aksu, M. (2018). A systematic review of flipped classroom studies in Turkish education. International Journal of Social Sciences and Education Research, 4(2), 207-229.

missed because of competitions and other events, and the instructors required the students to take notes on the videos and come to class with one thoughtful question to ask and share. The results showed that students began interacting more in the class and time could be used more efficiently and flexibly, and flipped classroom allowed them to spend much more time with students and to provide them with immediate feedback when needed (Ekmekçi, 2017) According to Tan et al. (2017), compared to traditional lecture-based classrooms; flipped classroom transforms learning from passive to an active process, facilitates learning by technology, allows more individualized guidance and practice and more in-class time to apply theoretical concepts in addition to the relation of learning content to the real-world scenarios, helps students to improve self-efficacy through self-studying, and lastly focuses on more challenging concepts and fosters critical thinking and problems-solving skills.

Flipped classroom is an instructional strategy that provides a new methodology and modality for teaching and learning by minimizing direct instruction in teaching and maximizing one-toone interaction and cooperative learning to encourage social interaction, teamwork and cultural diversity (Tan et al., 2017). Besides, problem solving, collaborative group works, self-evaluation, peer tutoring as the active learning strategies become more preferable for making students active in the environment (Kim, Kim, Khera \&Getman, 2014; McLaughlin \& Rhoney, 2015). Many studies have already reported that the flipped classroom had a positive effect on education outcomes, such as accelerating self-learning, improving academic performance or exploring students' perceptions and attitudes towards it (Başal, 2015; Bauer-Ramazani, Graney, Marshall \& Sabieh, 2016; Davies et al., 2013; Deslauriers, Schelew \& Wieman, 2011; Gençer, 2015; Huang\& Hong, 2015; Hung, 2015; Love, Hodge, Grandgenett \& Swift, 2014; Marcey\& Brint, 2011; McLaughlin, Roth, Glatt, Gharkholonarehe, Davidson, Griffin, Esserman \& Mumper, 2014; Nichols, 2012; Perez \& Riveros, 2014; Stone, 2012; Temizyürek\& Ünlü, 2015).

The purpose of this study to analyze the studies conducted in Turkey with a focus on comparison of the flipped classrooms with traditional lecture-based classrooms to see: i: to what extent flipped classrooms affect students' achievement, ii: how motivated students are in the flipped classrooms and what their attitudes are towards the use of flipped learning, and iii: what students' opinions are about the use of flipped classrooms.

\section{Literature}

The flipped classroom is an emerging pedagogical model in which traditional lecture is moved outside the classroom via technology and assigned as homework while in-class time is spent on collaborative inquiry-based learning (Bergman \& Sams, 2012; Johnson, Becker, Estrada\& Freeman, 2014; Lage, Platt, \& Treglia, 2000; Stone, 2012; Tucker, 2012). Besides, it is also a model which contributes to make learners take their own learning responsibilities (Fulton, 2012). The main goal is to provide learners a more authentic learning (Johnson et al., 2014). Moreover, flipped classroom results in greater teacher-student rapport and increased student-student interaction and more in-class time was allocated to conducting engaging activities (as cited in Kurt, 2017). The flipped classroom is defined by Bishop and Verleger (2013) as follows:

The flipped classroom is a new pedagogical method, which employs asynchronous video lectures and practice problems as homework, and active, group-based problem solving activities in the classroom. It represents a unique combination of learning theories once 
Tütüncü, N. Aksu, M. (2018). A systematic review of flipped classroom studies in Turkish education. International Journal of Social Sciences and Education Research, 4(2), 207-229.

thought to be incompatible- active, problem-based learning activities founded upon a constructivist ideology and instructional lectures derived from direct instruction methods founded upon behaviorist principles. (p. 1)

According to Yildırım and Kıray (2016), flipped classroom model provides an environment which include Project based or real world practices for learners in order to learn the subject better at class time. Moreover, the learners watch course videos, listen to podcasts, reach e-books and meet peers online instead of getting information from teacher only at class time as they can reach sources whenever they need.

Individualized and differentiated learning is enabled by integrating direct instruction and constructivist learning pedagogies. Learning is not limited within the classroom; students develop with an appropriate pace and direct their efforts to the points that they personally need. Students are expected to take the responsibility of their own learning. The teacher's role changes from the authority who organizes class time to a guide who provides asynchronous learning resources in case of need and effective FC classrooms share some common points: (1) students turn into active learners rather than passive listeners, (2) generally, technology enables putting less effort, (3) inclass time and traditional homework time change place and in-class time becomes more flexible in order to provide individualized learning, (4) the content includes real life scenarios and (5) inclass time is used either for enabling students to understand difficult concepts or making them participate in high-level critical thinking and problem solving activities (as cited in Boyraz \& Ocak, 2017). Educause (2012) described flipped learning as:

'..... a pedagogical model in which the typical lecture and homework elements of a course are reversed. Short video lectures are viewed by students at home before the class session, while in-class time is devoted to exercises, projects, or discussions. The video lecture is often seen as the key ingredient in the flipped approach, such lectures being either created by the instructor and posted online or selected from an online repository' (p. 1).

Although flipped learning is generally identified as including video lectures; pre-recorded lecture can be also in the forms of podcast or other audio format (Ekmekçi, 2017). Similarly, Bergman and Sams (2012) state that teacher-created videos that students watch are not the crucial point in flipped classrooms; yet how the best use of videos in-class-time with students is important (as cited in Ekmekçi, 2017) since active learning and participation, student involvement, blended course design, interaction of students with each other are emphasized (Educause, 2012). According to Yılmaz and Baydaş (2017), with the flipped classroom method, students read and view video lectures on an online platform at home before attending in-class sessions where they participate in more interactive and higher-order activities. The activities may be in the form of preclass asynchronous such as captured videos, interactive videos, online videos, podcasts, presentations, screencasts and notes or outside or in-class synchronous such as students' participation in problem-solving activities, presentations, discussions, debates or role-plays (as cited in Y1lmaz \& Baydaş, 2017). 
Tütüncü, N. Aksu, M. (2018). A systematic review of flipped classroom studies in Turkish education. International Journal of Social Sciences and Education Research, 4(2), 207-229.

A comparison of traditional and flipped classrooms in terms of activities is presented in Figure 1 below:

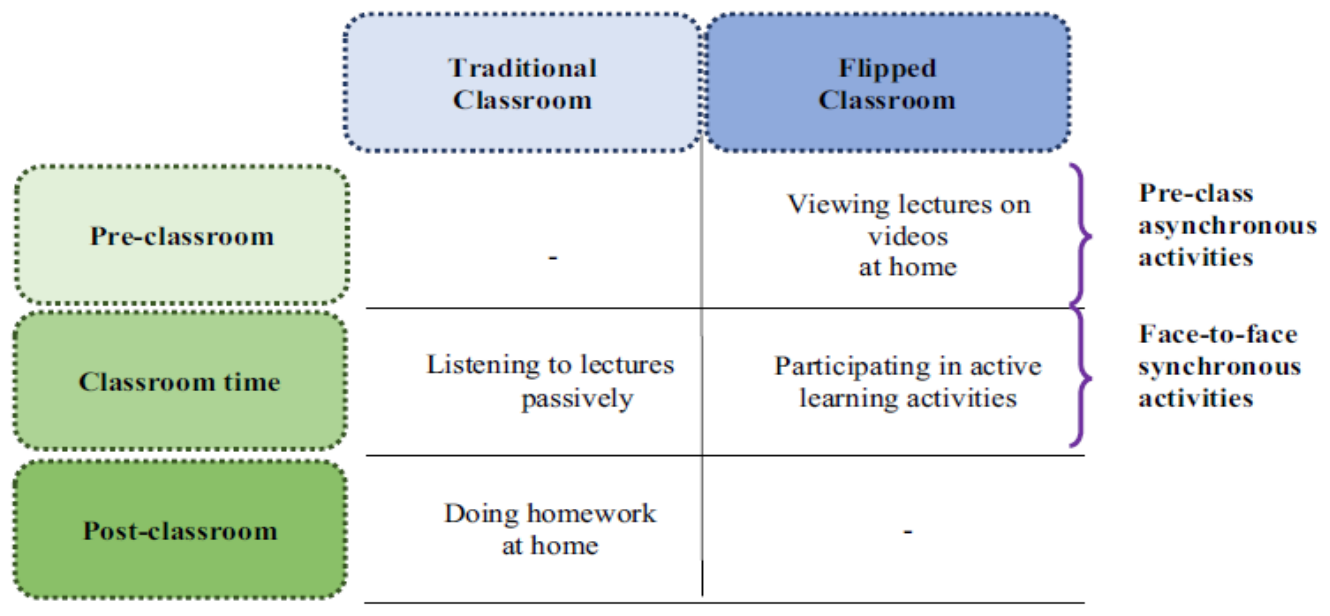

Figure 1. Summary of the Flipped Classroom Approach (Mok, 2014)

There are different flipped learning models with diverse focuses. While traditional "Flipped" Learning model by Khan Academy and "Flipped Mastery Model" by Bergmann and Sams (2012) focus on transferring content to students, Gerstein (2011) work on learning cycle of "Flipped Classroom Model", Staker and Horn (2012) concentrate on physical and virtual dimensions (as cited in Yildırım \& Kiray, 2016). Chen, Wang, Kinshuk \& Chen (2014) proposed a more comprehensive model for higher education where each letter symbolizes subscales:

$F$ - Flexible Environments

$L$ - Learner-Centered Approach

I- Intentional Content

$P$ - Professional Educators

$P$-Progressive Networking Learning Activities

$E$ - Engaging and Effective Learning Experiences

$D$ - Diversified and Seamless Learning Platforms

Lastly, there are lots of websites and application that can be used in flipped classrooms. Some of these applications and websites are Reef Polling, Kahoot, Moodle Mobile, Voscreen, Storylines, Teacherkit, Classroom, AudioLibrary, Zaption, Vivavideo, 30 Handstarter, Googledrive, SoundCloud, Keynote, Everynote Peek, Ibooks, Dropbox, Pages, Skitch, Penultimate, ShowMe, Notability, Screenchomp, Socrative Teacher Clicker, Educreation Whiteboard, Voice Thread, Edmodo, Phonics Genuis, Classdojo, Wordsalad, Kidblog, BrainPOP, Teachsmith Relay, Adobe Presenter 10, Microsoft Office Mix, Swivl, Voxer, Ourboox (Ceylaner, 2016).

\subsection{Framework of the flipped classroom}

Constructivism asserts that knowledge resides in individuals; that knowledge cannot be transferred intact from the head of a teacher to the heads of students. The student tries to make sense of what is taught by trying to fit it with his/her experience (Lorsbach \& Tobin, 1992). Moreover, the theory also implies that the learners or the individuals are constructors of their own knowledge which is generated by interacting with their socio-cultural environment (Vygotsky, 1978). In this sense, the roles or teachers and learners differentiate from traditional classrooms as teachers' 
Tütüncü, N. Aksu, M. (2018). A systematic review of flipped classroom studies in Turkish education. International Journal of Social Sciences and Education Research, 4(2), 207-229.

function is to arrange the conditions of learning (Gagne, 1985). Accordingly, it can be stated that flipped classroom model is based on constructivism in that students are given a chance to construct their own knowledge via elaborating on the topics before, during, and after class by themselves, as active learners, with the guidance of teachers in the learning process. Moreover, through interaction with their peers, they also construct knowledge through meaningful interactions in a social context. In other words, collaboration, interaction and engagement of learners in the flipped classroom, students "work through problems, advance concepts, and engage in collaborative activities which are effective in supporting their higher level of understanding (as cited in Kurt, 2017). Furthermore, emphasis on interaction among peers in classroom is basis for social constructivism which is supported in flipped classrooms via allocation of the class time activities to collaborative tasks rather than lecturing.

On the other hand, learners' readiness, autonomous learning, assimilation and accommodation of the information, discovery learning, development of problem solving skills from simple to complex ones and most importantly construction of their own knowledge through meaningful activities are supported in through the implementation of flipped learning. Hence, it can be stated that cognitive learning theory is also basis of flipped classrooms in terms of its interest in the mental side of learning. Since students can control their own learning as active learners in charge of their own learning process rather than memorization of the knowledge, they construct their own knowledge.

Moreover, Mastery Learning can be also seen in the design of flipped classrooms in that students are allowed to move at their own pace and can receive immediate feedback on their current level of mastery through the establishment of individualized learning opportunities. Like in mastery learning, instructors or teachers organize the concepts and skills they want to teach in the following class hour or week via videos and providing immediate feedback through the preparation of quizzes at the end of the flipped material, it helps students identify what they have learned well to that point and what they need to learn better (as cited in Guskey, 2005). Hence, the teachers can follow students' improvement, and suggest them extra materials in the class activities.

Furthermore, differentiated instruction is also evident in the flipped classroom (Kurt, 2017). Differentiating, or personalizing, instruction involves the identification of the needs and preferences of learners and the organization of instruction that is meaningful and relevant to their learning (Algozzine \& Anderson, 2007; Keefe, 2007). Similarly, students can watch the videos or complete the activities according to their own needs and preferences in accordance with their own pacing. Also, teachers, as facilitators or guides, can give immediate feedback to the students on their learning process, and differentiate their instruction and materials in the line with students' needs and pacing.

Lastly, flipped classroom's design is appropriate for the Bloom's taxonomy since students complete the lower forms of cognitive thinking (gaining knowledge and comprehension) outside the class while higher forms of cognitive thinking (application, analysis, evaluation ad creation) in class with the support of their peers and instructors (Brame, 2013). Unlike traditional classrooms, flipped classrooms encourages the development of higher thinking skills that students need to acquire the knowledge. While lecturing which includes lower level cognitive skills in Bloom's Taxonomy like remembering and understanding is the main activity in the classroom in TE, this situation is "flipped" and problem solving, experiments and doing exercises that require higher level cognitive skills in Bloom's Taxonomy like analyzing and creating replace lecturing 
Tütüncü, N. Aksu, M. (2018). A systematic review of flipped classroom studies in Turkish education. International Journal of Social Sciences and Education Research, 4(2), 207-229.

(Boyraz \& Ocak, 2017). The figure 2 below shows the difference between traditional classrooms and flipped classrooms in terms of the representation of the activities:

Traditional model

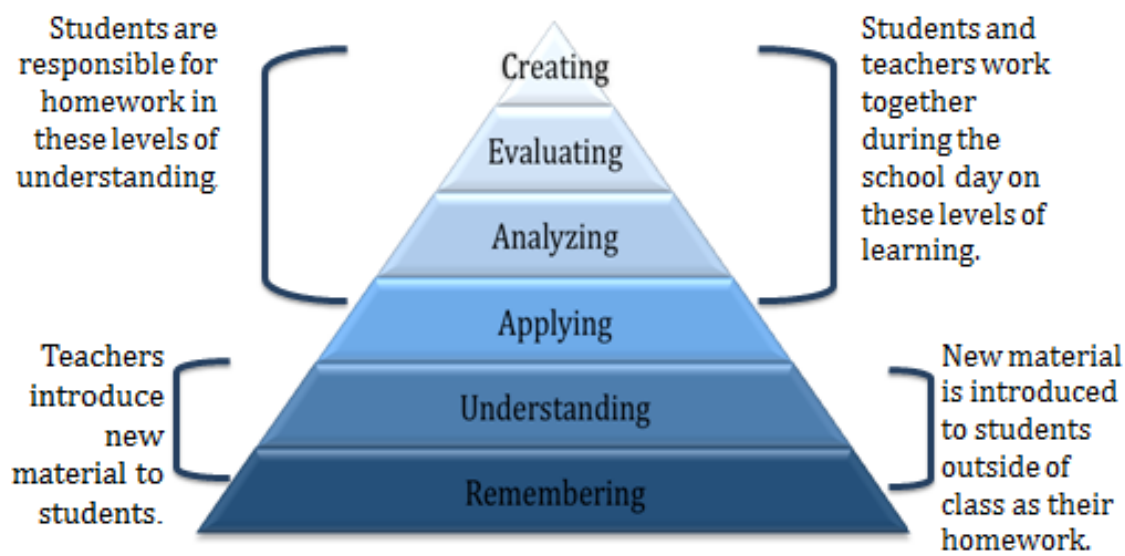

\section{Flipped model}

\section{Blooms Taxonomy}

Figure 2. Ways that Bloom's Taxonomy is applied to traditional vs. flipped classroom activities (Williams, 2013)

\subsection{The Advantages of flipped classroom}

The Flipped Classrooms which are called radical changes by Bergmann and Sams have many advantages for both teachers and students (as cited in Yıldırım \& Kıray, 2016). They also added that this is a good motivator for most of the students (Bergmann \& Sams, 2012) since the technological tools such as smartphones and tablet computers that are widely used by students in daily life are a widely used part of this method that increases students' motivation (Boyraz \& Ocak, 2017). The advantages can be ordered as in the following (Fulton, 2012; as cited in Yildirim \& Kıray, 2016):

- Each student can follow their courses according to their own understanding speed, there is opportunity to watch again and again if necessary.

- Homework is done in class; students can ask questions about the subjects they did not understand comfortably, educators may also provide suitable solutions according to the talent of the students.

- Students have a chance access course 7/24.

- Time spent in classroom is used more effectively in terms of both students and educators.

- Educators who have taught using this method indicated that they got higher results from the tests when compared to traditional method results.

- More time can be spent with students about the original research and students are able to spend more time with scientific equipment that can only be used in the classroom

- Students' being able to easily follow the classes which they couldn't because of sport, conference activities.

- Method pushes up student to think and study inside and outside the classroom - Students' being more active in the learning process. 
Tütüncü, N. Aksu, M. (2018). A systematic review of flipped classroom studies in Turkish education. International Journal of Social Sciences and Education Research, 4(2), 207-229.

- Students will participate to the learning environment more actively, and this will cause students to love the work they do.

Similarly, Bergmann, Overmeyer and Willie (2011) listed the advantages of flipped classrooms over traditional classrooms with three points: FC encourages life-long learning in that students have a chance to improve their knowledge to reach information through technology FC enables students to analyze the quality of materials by themselves via concentrating on its strengths and weaknesses, which helps them learn the subject better. FC increases the interaction between students and the school as a whole by means of increasing peer interaction and studentteacher interaction since students have to cooperate with each other to complete the tasks in the classrooms.

\subsection{The limitations and disadvantages of flipped classroom}

The disadvantages of flipped classrooms may be caused by materials, teachers, and students. In terms of the materials, the need for computers and internet connection (Duerden, 2013; Jenkins, 2012; Miller, 2012; Y1ldirım \& Kiray, 2016) and the need to find quality videos or sources (Talbert\& Valley, 2012). On the other hand, giving responsibility of both preparation and following students' online activities to the teachers can be difficult for them due to time allocation and their adaptation problems (as cited in Y1ldırım\& Kiray, 2016). Lastly, students may have difficulty in adaptation to the new methods and may have difficulty in understanding the subject on their own in the beginning (as cited in Yıldırım\& Kıray, 2016).

\section{Methodology}

A systematic review was carried out in 8 databases: EBSCOhost, ERIC, Web of Science, Science Direct, Ulakbim, CoHE, DOAJ and JSTOR. The following search terms included: flipped, flipped learning, flipped classroom, ters yüz öğrenme and each word/ word group searched in combination with Turkey and Turkish education. Besides, reference lists of relevant identified articles were hand searched on Google scholar. The search was completed on January 10, 2018. Refereed journal publications from 2014 to 2017 inclusive were identified. A total of 1003 records were searched in the beginning, and the search strategy focused on the title, keywords and abstract of each record. 338 articles retrieved after the removal of duplicates.

The inclusion criteria as displayed in the PRISMA diagram below are: a) contemporary research articles dating from 2014 to 2017, b) context: studies conducted in Turkey, sampling Turkish population, c) language: studies published in English and Turkish, d) source: peer-reviewed articles, theses and dissertations open to access, e) type: research articles and exclusion of review articles, conference proceedings or book chapters, and f) interest: implementation of flipped learning in comparison to traditional lecture-based classrooms. After the implementation of the inclusion and exclusion criteria, 38 studies were found eligible for the review. Accordingly, 27 research articles, 9 master's theses and $2 \mathrm{PhD}$ dissertation were found suitable for the review. Among the studies, 7 of them are qualitative, 11 of them are quantitative and lastly 20 of the 
Tütüncü, N. Aksu, M. (2018). A systematic review of flipped classroom studies in Turkish education. International Journal of Social Sciences and Education Research, 4(2), 207-229.

studies are mixed-method design. Graphic 1 shows the distribution of studies in terms of the years studies conducted and research design below:

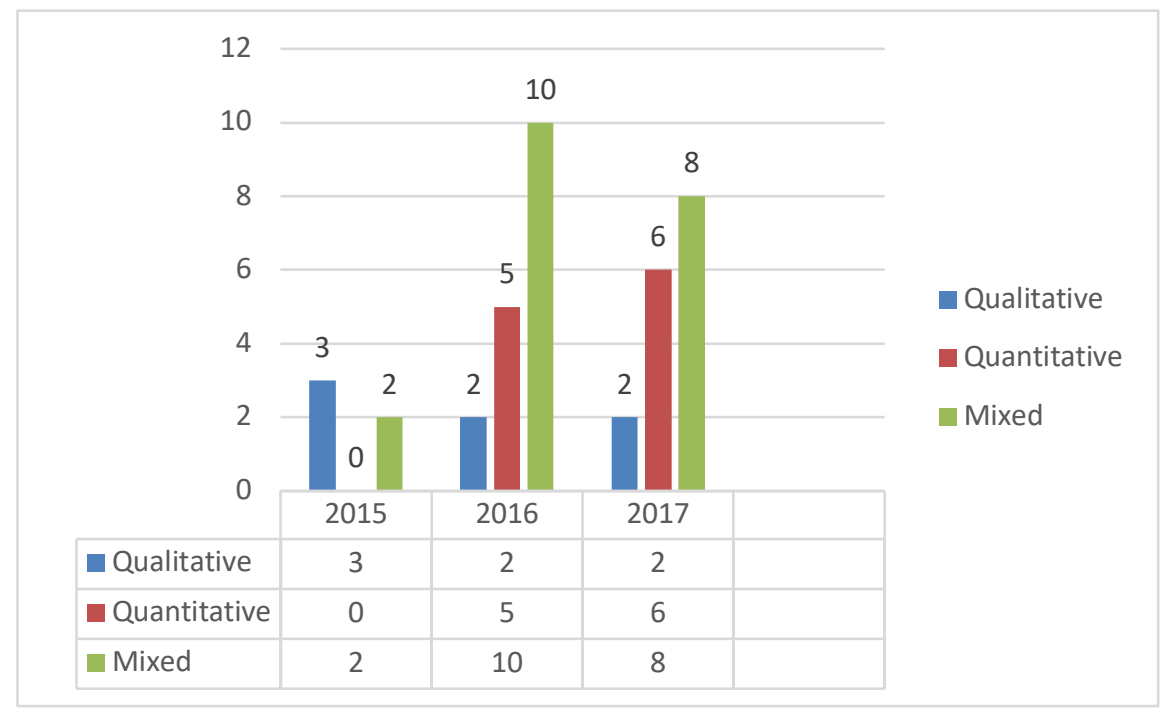

Graphic 1. The distribution of the flipped classroom studies in education in Turkey with respect to year

Following the analysis of the articles, major themes that the studies analyzed in comparison with traditional lecture-based teaching were found out. Appendix 1 presents a detailed information about the studies included in the review with their author/s, publication year, purpose, study design, sample (population and number of the participants) and lastly the major themes found in the study.

\section{Results and Conclusion}

The four themes identified from the review of Table 1 and Table 2 (please see Appendix 1) are achievement in the flipped classrooms; and perspectives, attitudes and motivations of the students towards flipped classrooms. The results of each part are displayed in detail below:

\subsection{Achievement}

27 of the studies compared the achievement scores of students in flipped classroom and traditional lecture-based classrooms. Accordingly, 25 studies exclusively reported that students taught by flipped classroom outperformed the ones taught by traditional lecture-based classrooms. Of these, 23 of them reported the statistical significance of their findings (Adnan, 2017; Akgün \& Atıc1, 2017; Alsancak- Sırakaya, 2015; Aşıksoy\& Özdamlı, 2016; Aydın, B., 2016; Boyraz \& Ocak, 2017; Çakır, 2017; Çalışkan, 2016; Çetin- Köroğlu \& Çakır, 2017; Ekmekçi, 2017; Güç, 2017; Göğebakan-Atıcı \& Y1ldı,, 2016; Göğebakan-Atıc1, Yıldız \& Altınbaş, 2016; Karaca \& Ocak, 2017; Kurt, 2017; Sağlam, 2016; Sarıgöz, 2017; Şahin, Cavlazoğlu \& Zeytuncu, 2015; Şengel, 2016; Turan, 2015; Tugun, Uzunboylu \& Özdaml1, 2017; Umutlu, 2016; Zengin, 2017). In others, authors reported an increase in the average scores, yet did not report a statistical analysis investigating the significance of the observed difference (Özpınar, Yenmez \& Gökçe, 2016; Sezer, 2016). Lastly, two studies found no significant difference in students' achievement scores (Aydın, G., 2016; Yavuz, 2016). On the other hand, one study examining three different achievement reports (midterm, portfolio, and essay scores) found no difference in flipped and traditional 
Tütüncü, N. Aksu, M. (2018). A systematic review of flipped classroom studies in Turkish education. International Journal of Social Sciences and Education Research, 4(2), 207-229.

classrooms in two of them (midterm and portfolio grades), yet a significant difference in one area (essay scores) (Adnan, 2017).

\subsection{Perspectives/opinions/views}

25 of the studies examined learners' perspectives about the use of flipped classrooms. In terms of students' opinions related to flipped classrooms, positive opinions were stated in all the studies: better preparation for the courses ( Akgün \& Atıc1, 2017; Alsancak- Sirakaya, 2015; Aydın, B., 2016; Başal, 2015; Boyraz \& Ocak, 2017; Çukurbaş \& Kıyıc1, 2016; Göğebakan-Yıldız, Kıyıcı \& Altıntaş, 2016;Görü-Doğan, 2015; Özyurt\& Özyurt, 2017; Şahin, Cavlazoğlu, Zeytuncu, 2015; Turan, 2015; Urfa \& Durak, 2017; Yavuz, 2016; Y1lmaz, 2017), becoming active-learners in the classrooms (Akgün \& Atıc1, 2017; Alsancak- Sırakaya, 2015; Aşıksoy, Özdamlı, 2016; Başal, 2015; Çalışkan, 2016; Çukurbaş \& Kıyıc1, 2016; Güç, 2017; Özpınar, Aydoğan-Yenmez, Gökçe, 2016; Şahin, Cavlazoğlu, Zeytuncu, 2015; Turan, 2015; Urfa \& Durak, 2017; Yavuz, 2016; Yılmaz, 2017; Zeren, 2016) more practice opportunities (Adnan, 2017; Aşıksoy, Özdaml1, 2016; Çalışkan, 2016; Çukurbaş \& Kıyıcı, 2016; Göğebakan-Yıldız, Kıyıcı \& Altıntaş, 2016; Kocabatmaz, 2016; Kurt, 2017; Turan, 2015; Zeren, 2016), more real-life contexts (Çalışkan, 2016), socially and psychologically relaxed atmosphere and better less-stressful learning environment (Çalışkan, 2016; Kurt, 2017;Tugun, Uzunboylu \& Özdaml1, 2017; Yılmaz, 2017), student-centered learning environment (Alsancak- Sirakaya, 2015; Kurt, 2017; Urfa \& Durak, 2017), easy time-management (Çalışkan, 2016), more enjoyable classes (Aydın, B., 2016; Kurt, 2017; Göğebakan-Yıldız, Kıyıcı \& Altıntaş, 2016; Özpınar, Aydoğan-Yenmez, Gökçe, 2016; Şengel, 2016; Tugun, Uzunboylu \& Özdaml1, 2017; Turan, 2015; Urfa \& Durak, 2017; Yavuz, 2016; Y1lmaz, 2017), easy access to the materials (Adnan, 2017; Alsancak- Sirakaya, 2015; Aşıksoy, Özdaml1, 2016; Çukurbaş \& Kıyıc1, 2016; Kocabatmaz, 2016; Urfa \& Durak, 2017; Yavuz, 2016), self-pace learning (Akgün \& Atıc1, 2017; Aşıksoy, Özdamlı, 2016; Aydın, B., 2016; Başal, 2015; Kurt, 2017; Güç, 2017; Tugun, Uzunboylu \& Özdaml1, 2017; Yavuz, 2016),repetition of the content (Alsancak- Sırakaya, 2015; Aşıksoy, Özdaml1, 2016; Çukurbaş \& Kıyıcı, 2016; Kocabatmaz, 2016; Turan, 2015; Yavuz, 2016), promotion of knowledge retention (Akgün \& Atıc1, 2017; Göğebakan-Yıldız, Kıyıcı \& Altıntaş, 2016; Görü-Doğan, 2015; Kocabatmaz, 2016; Kurt, 2017; Şahin, Cavlazoğlu, Zeytuncu, 2015; Urfa \& Durak, 2017), easier comprehension of the content (Akgün \& Atıc1, 2017; Boyraz \& Ocak, 2017; Göğebakan-Yıldız, Kıyıcı \& Altıntaş, 2016; Güç, 2017; Kocabatmaz, 2016; Özpınar, Aydoğan-Yenmez, Gökçe, 2016; Özyurt\& Özyurt, 2017; Tugun, Uzunboylu \& Özdaml1, 2017; Zeren, 2016), increase cooperation and interaction among peers (Akgün \& Atıcı, 2017; Aydın, B., 2016; Çalışkan, 2016; Çukurbaş \& Kıyıc1, 2016; Göğebakan-Yıldız, Kıyıcı \& Altıntaş, 2016; Görü-Doğan, 2015; Güç, 2017; Kocabatmaz, 2016; Özpınar, Aydoğan-Yenmez, Gökçe, 2016; Turan, 2015; Y1lmaz, 2017), increase in self-confidence (Adnan, 2017; Güç, 2017; Şahin, Cavlazoğlu, Zeytuncu, 2015; Tugun, Uzunboylu \& Özdaml1, 2017; Yavuz, 2016), increase in motivation (Çukurbaş \& Kıyıc1, 2016; Sezer, 2016; Şengel, 2016; Tugun, Uzunboylu \& Özdaml1, 2017), improvement in self-regulation, self-discipline and learner autonomy (Adnan, 2017; Zeren, 2016), better student-teacher interaction (Akgün \& Atıc1, 2017; Adnan, 2017; Çalışkan, 2016; Kocabatmaz, 2016; Özpınar, Aydoğan-Yenmez, Gökçe, 2016; Turan, 2015); with a few problems: duration of the videos (Adnan, 2017; Çukurbaş \& Kıyıc1, 2016; Turan, 2015;), limited time to the completion of the tasks (Adnan, 2017; Göğebakan-Yıldız, Kıyıcı \& Altıntaş, 2016; Kocabatmaz, 2016; Özpınar, Aydoğan-Yenmez, Gökçe, 2016; Yavuz, 2016; Y1lmaz, 2017), unfamiliarity to the method (Kocabatmaz, 2016; Tugun, Uzunboylu \& Özdaml1, 2017; Urfa \& Durak, 2017), computer and internet problems (Aydın, B., 
Tütüncü, N. Aksu, M. (2018). A systematic review of flipped classroom studies in Turkish education. International Journal of Social Sciences and Education Research, 4(2), 207-229.

2016; Boyraz \& Ocak, 2017; Çukurbaş \& Kıyıc1, 2016; Görü-Doğan, 2015; Kocabatmaz, 2016; Tugun, Uzunboylu \& Özdaml1, 2017; Tugun, Uzunboylu \& Özdaml1, 2017; Turan, 2015; Urfa \& Durak, 2017; Yavuz, 2016), not receiving immediate feedback (Göğebakan-Yıldız, Kıyıcı \& Altıntaş, 2016; Özpınar, Aydoğan-Yenmez, Gökçe, 2016). Moreover, in one study, students stated that traditional approach is more effective (Aşıssoy, G. \& Özdaml1, F., 2016).

\subsection{Motivation}

The results of the studies in terms of motivation showed that students taught in flipped classrooms have more motivations than students taught in traditional classrooms (Alsancak-Sirakaya, 2015; Aş1ksoy\& Özdaml1, 2016; Sezer, 2016; Özpinar, Aydoğan-Yenmez \& Gökçe, 2016; Turan, 2015; Y1lmaz, 2017). However, there was also increase in the motivation levels taught in traditional classrooms, and it is suggested that this may be caused by different motivation levels, and flipped classroom is still more effective in improving students' motivation levels compared with the traditional method (Sezer, 2016).

\subsection{Attitudes}

The results of the studies revealed that students in the flipped classrooms have positive attitudes towards flipped instruction (Ceylaner, 2016; Çetin- Köroğlu \& Çakır, 2017; Ekmekçi, 2017; Sağlam, 2016; Y1lmaz, 2017). The qualitative results showed that Flipped Writing Class Model is more enjoyable than traditional lecture-based writing classes (Ekmekçi, 2017), and a great deal of enjoyment in favor of flipped classroom was found out (Çetin- Köroğlu \& Çakır, 2017; Ekmekçi, 2017; Yılmaz, 2017). However, two of the studies found no significant difference in students' attitudes towards the flipped classroom (Aydın, G. 2016; Güç, 2017).

\subsection{Discussion of the findings}

This systematic review highlights crucial findings on the current status of research on the flipped classroom in Turkey. In general, the results of this systematic review show that the number of studies focusing on flipped classrooms in the context of Turkey is increasing (16 of the studies were conducted in 2017, 17 of them were conducted in 2016, and 5 of them were conducted in 2015). Moreover, the results also display that studies are mostly conducted in higher education context (30 of the studies were conducted in higher education context, and 4 of them were conducted in secondary education, and lastly 4 of them was conducted in primary education context. The focuses of the studies are on the students' achievement in flipped classrooms in comparison with traditional lecture-based classrooms; students' perspectives on the use of flipped classrooms; and lastly the effect of flipped classrooms on students' motivation and attitudes towards the subjects and flipped classroom implementation.

In terms of the comparison of students' achievement in flipped classrooms and that in traditional lecture-based classrooms, the reviewed studies in Turkey have parallel results with the previous studies since they reported that students became more successful in flipped classrooms and there was an increase in their achievement scores. In the same way, the achievement scores (academic performance, academic achievement, learning gains, performance increase or exam-based scores) of students taught by flipped classrooms compared to students' scores in traditional lecture- based classrooms in international studies previously showed that students in flipped classrooms outperformed the ones in traditional classrooms (Deslauriers, Schelew \& Wieman, 2011; Huang \& Hong, 2015; Hung, 2015; Love et al., 2014; Marcey \& Brint, 2011; McLaughlin \& 
Tütüncü, N. Aksu, M. (2018). A systematic review of flipped classroom studies in Turkish education. International Journal of Social Sciences and Education Research, 4(2), 207-229.

Rhoney., 2015; Stone, 2017). Similarly, the results of this review showed that students in flipped classrooms had higher scores than the ones in traditional classrooms.

Regarding students' perceptions/ opinions or views about flipped classrooms, the review displayed similar results since the previous studies reported that learning environment was taught to be more flexible (Kiat \& Kwot, 2014; Mok, 2014; Simpson, Evans, Eley, \& Stiles, 2003), it fosters peer interaction and cooperation (Bailey \& Smith, 2013; Love et al., 2014; Talbert \& Valley, 2012), students come to class prepared ( Mok, 2014), they preferred flipped classroom over traditional methods (Butt, 2014; Gilboy, Heinerichs \& Pazzaglia, 2015; Love et al., 2014; Roach, 2014), they developed a better comprehension of the content (Simpson \& Richards, 2015). In terms of the disadvantages and limitations, studies reported that students found the lecture videos boring and long (Amresh, Carberry \& Femiani, 2013; Olson, 2014; Ossman\& Warren, 2014), they experienced technical problems related to the computers and internet connection (Everett, Morgan, Stanzione\& Mallouk, 2014; Tague \& Baker, 2014), and they had problems due to their lack of readiness and unfamiliarity to the method (Amresh et al., 2013; Bland, 2006; Margoniner, 2014; Talbert \& Valley, 2012).

Concerning the effect of flipped classroom on students' motivation, the findings revealed that students' motivations were higher in flipped classrooms in comparison to the motivation increase observed in students in traditional lecture-based classrooms. These findings echo earlier studies in that flipped classrooms were reported as a promising method to increase students' motivation (Chen et al., 2014; Chen, Lui \& Martinelli, 2017; Davies et al., 2013; Tune, Sturek \& Basile, 2013).

Lastly, on the subject of students' attitudes, the findings demonstrated that students had positive attitudes towards flipped learning as they reported that they had more fun and felt less anxious as they got higher achievement and they assumed the classroom as a less stressful learning environment. The results were similar to the previous studies reporting that students hold positive attitudes (Marcey \& Brint, 2011; Stone, 2012; Sun, 2017; Valeo, 2013).

\section{Conclusion}

Findings from this review suggest that flipped classrooms is an effective method compared to traditional lecture-based classrooms, particularly when the purpose is to increase students' achievement, to develop positive attitudes and to increase their motivation towards the course. Moreover, except from the technical problems students experienced, they mostly asserted positive opinions about the flipped classrooms. Since the profile of the learners is changing thanks to the integration of technology into our lives, the change in instructional materials and strategies is unavoidably necessary to get benefit most for the sake of learners' development. Therefore, there should be more studies implementing the flipped classroom in Turkish context by bearing in mind its benefits and advantages over traditional teaching methods.

\section{References}

Adnan, M. (2017) Perceptions of senior-year ELT students for flipped classroom: a materials development course. Computer Assisted Language Learning, 30 (3-4), 204-222, DOI: 10.1080/09588221.2017.1301958.

Akgün, M. \& Atıc1, B. (2017). The effect of flipped classroom on learners' academic achievements and views. Kastamonu Journal of Education, 25(1), 329-344. 
Tütüncü, N. Aksu, M. (2018). A systematic review of flipped classroom studies in Turkish education. International Journal of Social Sciences and Education Research, 4(2), 207-229.

Aşıksoy, G. \& Özdamlı, F. (2016). Flipped Classroom adapted to the ARCS model of motivation and applied to a physics course. Eurasia Journal of Mathematics, Science \& Technology Education, 12(6), 1589-1603.

Algozzine, B., \& Anderson, K. M. (2007). Tips for teaching: Differentiating instruction to include all students. Preventing School Failure: Alternative Education for Children and Youth, 51(3), 49-54.

Alsancak Sirakaya, D. (2015). The effect of flipped classroom model on academic achievement, self-directed learning readiness and motivation. (doctoral dissertation). Gazi University, Ankara, Turkey.

Amresh, A., Carberry, A. R., \& Femiani, J. (2013). Evaluating the effectiveness of flipped classrooms for teaching CS1. Proceedings of the 2013 Frontiers in Education Conference, Oklahoma City, OK, 733735.

Azemi A (2013). Teaching electric circuits using a modified flipped classroom approach. I Proceedings of the 2013 Frontiers in Education Conference, Oklahoma City, OK, 309-310.

Aydın, B. (2016). The effects of flipped classroom model on academic achievement, homework/task stress level and transfer of learning. (master's thesis). Süleyman Demirel University, Isparta, Turkey.

Aydın, G. (2016). Ters yüz sinlf modelinin üniversite öürencilerinin programlamaya yönelik tutum, özyeterlilik algısı ve başarllarına etkisinin incelenmesi. (master's thesis). Dokuz Eylül University, İzmir, Turkey.

Bailey, R., \& Smith, M. C. (2013). Implementation and assessment of a blended learning environment as an approach to better engage students in a large systems design class. Proceedings of 120 th ASEE Annual Conference \& Exposition. Atlanta, GA.

Baker, J. W., \& Mentch, M. W. (2000). IMOWA curriculum materials. http://www.imowa.org/curricula/flip/

Başal, A. (2012). The use of flipped classroom in foreign language teaching, Proceedings of the 3 rd Black Sea ELT Conference Technology: A Bridge to Language Learning, 8-13.

Barak, M., Harward, J., Kocur, G., \& Lerman, S. (2007). Transforming an introductory programming course: From lectures to active learning via wireless laptops. Journal of Science Education and Technology, 16(4), 325-336.

Başal, A. (2015). The implementation of a flipped classroom in foreign language teaching. Turkish Online Journal of Distance Education (TOJDE), 16(4-3), 28-37.

Bauer-Ramazani, C., Graney, J. M., Marshall, H. W., \& Sabieh, C. (2016). Flipped Learning in TESOL: Definitions, Approaches, and Implementation. TESOL Journal, 7(2), 429-437.

Bergmann, J., \& Sams, A. (2012). Flip your classroom: Reach every student in every class every day. Alexandria, VA: International Society for Technology in Education.

Bergmann, J., Overmeyer, J., \& Willie, B. (2013). The flipped class: what it is and what it is not. The Daily Riff. Retrieved January 6, 2018, from http://www.thedailyriff.com/articles/the-flipped-class-conversa$\underline{\text { tion-689.php }}$

Bishop, J.L. \& Verleger, M.A. (2013). The flipped classrom: A survey of the research, American Society for Engineering Education (ASEE) National Conference Proceedings, Atlanta, GA. Retrieved from http://www.asee.org/public/conferences/20/ papers/6219/view.

Bland, L. (2006). Apply flip/inverted classroom model in electrical engineering to establish life-long learning. ASEE Annual Conference. Chicago, IL.

Brame, C., (2013). Flipping the classroom. Retrieved January 5, 2018, from http://cft.vanderbilt.edu/guides-sub-pages/flipping-the-classroom/.

Boyraz, S., \& Ocak, G. (2017). Implementation of flipped education into Turkish EFL teaching context. Journal of Language and Linguistic Studies, 13(2), 426-439.

Butt, A. (2014). Student Views on The Use of A Flipped Classroom Approach: Evidence From Australia. Business Education \& Accreditation, 6(1), 33-43. 
Tütüncü, N. Aksu, M. (2018). A systematic review of flipped classroom studies in Turkish education. International Journal of Social Sciences and Education Research, 4(2), 207-229.

Ceylaner, S. (2016). Effects of flipped classroom on students' self-directed learning readiness and attitudes towards English lesson in the $9^{\text {th }}$ grade English language teaching. (master's thesis). Mersin University, Mersin, Turkey.

Chen, F., Lui, A. M. \& Martinelli, S. M. (2017). A systematic review of the effectiveness of flipped classrooms in medical education. Medical Education, 51, 585-597.

Chen, Y., Wang, Y., Kinshuk \& Chen, N.S. (2014). Is FLIP enough? or should we use the FLIPPED model instead? Computers \& Education, 79, 16-27.

Çakır, E. (2017). The effect of flipped classroom on $7^{\text {th }}$ grade students' academic achievement, cognitive risk taking skills and computational thinking skills in science education classrooms. (master's thesis). Ondokuz Mayıs University, Samsun, Turkey.

Çalışkan, N. (2016). Examining the influence of flipped classroom on students' learning English as a foreign language (master's thesis). Çağ University, Mersin, Turkey.

Çelebi, H., Karaaslan,H., \& Demir-Vegter, S. (2016). The title of your paper: Corpus use in enhancing lexico-grammatical awareness through flipped applications. Journal of Language and Linguistic Studies, 12(2), 152-165.

Çetin Köroğlu, Z. \& Çakır, A. (2017). Implementation of flipped instruction in language classrooms: an alternative way to develop speaking skills of pre-service English language teachers. International Journal of Education and Development using Information and Communication Technology (IJEDICT), $13(2), 42-55$.

Çukurbaşı, B. \& Kiyici, M. (2017). Preservice teachers' views about flipped classroom model. Bayburt Journal of Educational Sciences, 12(23), 87-102.

Davies, R. S., Dean, D. L., \& Ball, N. (2013). Flipping the classroom and instructional technology integration in a college-level information systems spreadsheet course. Educational Technology Research and Development, 61(4), 563-580.

Deslauriers, L., Schelew, E., \& Wieman, C. (2011). Improved learning in a large enrollment physics class. Science, 332(6031), 862-864.

Duerdan, D. (2013). Disadvantages of a Flipped Classroom. Retrieved from http://www.360-edu.com/commentary/disadvantagesof-a-flipped-classroom.htm\#. UtaQkvRdUpW.

Educause. (2012). 7 things you should know about flipped classrooms. Retrieved from: http://net.educause.edu/ir/library/pdf/ELI7081.pdf

Ekmekçi, E. (2017). The flipped writing classroom in Turkish EFL context: a comparative study on a new model. Turkish Online Journal of Distance Education (TOJDE), 18 (2-12), 151-167.

Everett, J. W., Morgan, J. K., Stanzione, J. F., \& Mallouk, K. E. (2014). A hybrid flipped first-year engineering course. Paper presented at Proceedings of 121st ASEE Annual Conference \& Exposition, Indianapolis, IN.

Fulton, K. P. (2012). 10 reasons to flip. Phi Delta Kappan, 94(2), 20-24.

Gagné, F. (1985). Giftedness and talent: Reexamining a reexamination of the definitions. Gifted Child Quarterly, 29(3), 103-112.

Gençer, B. G. (2015). Okullarda ters-yüz sınıf modelinin uygulanmasına yönelik birvaka çalışması. Yayımlanmamış Yüksek Lisans Tezi, Eğitim Bilimleri Enstitüsü Bahçeşehir Üniversitesi. İstanbul.

Gilboy, M. B., Heinerichs, S. ve Pazzaglia, G. (2015). Enhancing student engagement using the flipped classroom. Journal of nutrition education and behavior, 47(1), 109-114.

Göğebakan Yıldız, D. \& Kıyıcı, G. (2016). Effect of the flipped classroom on prospective teachers' academic achievement, metacognitive awareness and epistemological beliefs. CBÜ University Journal of Social Sciences, 14(3), 405-426.

Göğebakan Yıldız, D., Kıyıcı, G. \& Altıntaş, G. (2016). A research into the flipped classroom in terms of the academic achievement, and views of prospective teachers. Sakarya University Journal of Education, 6(3), 186-200. 
Tütüncü, N. Aksu, M. (2018). A systematic review of flipped classroom studies in Turkish education. International Journal of Social Sciences and Education Research, 4(2), 207-229.

Görü Doğan, T. (2015). Using the social media in instructional processes: learner opinions on the flipped learning approach, $A U A d, 1(2), 24-48$.

Güç, F. (2017). The effect of flipped classroom practice on the rational numbers and operations with rational numbers. (master's thesis). Amasya University, Amasya, Turkey.

Guskey, T. R. (2005). Formative Classroom Assessment and Benjamin S. Bloom: Theory, Research, and Implications. Online Submission.

Hung, H. (2015). Flipping the classroom for English language learners to foster active learning. Computer Assisted Language Learning, 28(1), 81-96.

Huang, Y. N., \& Hong, Z. R. (2015). The effects of a flipped English classroom intervention on students' information and communication technology and English reading comprehension. Educational Technology Research and Development, 1-19.

Johnson, L., Becker, S., Estrada, V., \& Freeman, A. (2014). Horizon Report: 2014 Higher Education.

Jenkins, C. (2012). The Advantages and Disadvantages of the flipped classroom. The Lecture Tools Blog, Posted by Chelsea Jenkins.

Karaca, C.\& Ocak, M. A. (2017). Effects of flipped learning on university students' academic achievement in algorithms and programming education. International Online Journal of Educational Science, 9(2), 527-543.

Keefe, J. W. (2007). What is personalization? Phi Delta Kappan, 89(3), 217-223.

Kiat, P. N., \& Kwot, Y. T. (2014). The flipped classroom experience. In Proceedings of IEEE CSEE\&T, Klagenfurt, Austria: IEEE Xplore Digital Library, 39-43.

Kim, M. K., Kim, S. M., Khera, O., \& Getman, J. (2014). The Experience of three flipped classrooms in an urban university: an exploration of design principles. The Internet and Higher Education, 22, 37-50.

Kocabatmaz, H. (2016). The ideas of pre-service teachers regarding the flipped classroom model. Journal of Research in Education and Teaching, 5(4), 14-24.

Kurt, G. (2017). Implementing the Flipped Classroom in Teacher Education: Evidence from Turkey. Educational Technology \& Society, 20 (1), 211-221.

Lage, M.J., Platt, G.J. \& Treglia, M (2000). Inverting the classroom: A gateway to creating an inclusive learning environment. The Journal of Economic Education, 31(1), 30-43.

Lorsbach, A., \& Tobin, K. (1992). Constructivism as a referent for science teaching. NARST Newsletter, 30, $5-7$.

Love, B., Hodge, A., Grandgenett, N., \& Swift, A. W. (2014). Student learning and perceptions in a flipped linear algebra course. International Journal of Mathematical Education in Science and Technology, 45(3), 317-324.

Marcey, D. \& Brint, M. (2011). Transforming an Undergraduate Introductory Biology Course Through Cinematic Lectures and Inverted Classes: A Preliminary Assessment of The Clic Model Of The Flipped Classroom. California Lutheran University, Thousand Oaks, CA.

Marbach-Ad, G., \& Sokolove, P. G. (2002). The Use of e-mail and in-class writing to facilitate studentinstructor interaction in large-enrollment traditional and active learning classes. Journal of Science Education and Technology, 11(2), 109-119.

Margoniner, V. (2014). Learning gains in introductory astronomy: Online can be as good as face-to-face. The Physics Teacher, 52, 298-301.

McLaughlin, J. E., \& Rhoney, D. H. (2015). Comparison of an interactive e-learning preparatory tool and a conventional downloadable handout used within a flipped neurologic pharmacotherapy lecture. Currents in pharmacy teaching and learning, 7(1), 12-19.

McLaughlin, J.E., Roth, M.T., Glatt, D.M., Gharkholonarehe, N., Davidson, C. A., Griffin, L.M., Esserman, D.A. \& Mumper R.J. (2014). The flipped classroom: A course redesign to foster learning and engagement in a health professions school. Academic Medicine 89(2), 236-243. 
Tütüncü, N. Aksu, M. (2018). A systematic review of flipped classroom studies in Turkish education. International Journal of Social Sciences and Education Research, 4(2), 207-229.

Miller, A. (2012). Five best practices for the flipped classroom. Edutopia, 24(02), 12.

Mok, H. N. (2014). Teaching tip: The flipped classroom. Journal of Information Systems Education, 25(1), 7.

Nichols, D. (2012). Flip Classroom Instruction: How to Guide Part 1 -- Educational technology tips. Educational Technology Tips.

Olson, R. (2014). Flipping engineering probability and statistics - Lessons learned for faculty considering the switch. Paper presented at Proceedings of the 121st ASEE Annual Conference \& Exposition, Indianapolis, IN.

Ossman, K. A., \& Warren, G. (2014). Effect of flipping the classroom on student performance in first year engineering courses. Paper presented at Proceedings of the 121 st ASEE Annual Conference \& Exposition, Indianapolis, IN.

Ozdamli, F. \& Asiksoy, G. (2016). Flipped classroom approach. World Journal on Educational Technology: Current Issues. 8(2), 98-105.

Özpınar, İ., Aydoğan Yenmez, A. \& Gökçe, S. (2016). An application of flipped classroom model in the instructional technologies and material development course. Journal of Education and Training Studies, 4(12), 213-226.

Özyurt, Ö. \& Özyurt, H. (2017). A qualitative study about enriching programming and algorithm teaching with flipped classroom approach. Pegem Eğitim ve Ögretim Dergisi, 7(2), 189-210.

Prensky, M. (2001). Digital natives, digital immigrants. On the Horizon, 9(5), 1-6.

Pérez, D. P., \& Riveros, R. M. (2014). Unleashing The Power Of Blended Learning And Flipped Classroom For English As A Foreign Language Learning: Three Spheres Of Challenges And Strategies In A Higher Education Institution In Colombia. Proceedings of ICERI2014 Conference 17th-19th November, 2014, Seville, Spain.

Roach, T. (2014). Student perceptions toward flipped learning: New methods to increase interaction and active learning in economics. International Review of Economics Education, 17, 74-84.

Sağlam, D. (2016). The effect of flipped classroom on the academic achievement and attitudes of students in English language teaching. (master's thesis). Bülent Ecevit University, Zonguldak, Turkey.

Sarıgöz, O. (2017). An analytical study related learning with flipped classroom model. Mustafa Kemal University Journal of Social Sciences Institute, 14(38), 1-11.

Sezer, B. (2017). The effectiveness of a technology-enhanced flipped science classroom. Journal of Educational Computing Research, 55(4), 471-494.

Simpson, W., Evans, D., Eley, R., \& Stiles, M. (2003). Findings from the HEI "Flip" project: Application issues. International Journal of Continuing Engineering Education and Lifelong Learning, 13(5), 471482 .

Simpson, V. \& Richards, E. (2015). Flipping the classroom to teach population health: increasing the relevance. Nurse Education in Practice, 15(3), 162-167.

Staker, H., \& Horn, M. B. (2012). Classifying $K-12$ blended learning. Retrieved from http://www.innosightinstitute.org/innosight/wp-content/uploads/2012/05/Classifying-K-12-blendedlearning2.pdf

Stone, B. B. (2012). Flip your classroom to increase active learning and student engagement. In Proceedings from $28^{\text {th }}$ Annual Conference on Distance Teaching \& Learning, Madison, Wisconsin, USA.

Sun, Y. C. (2017). Flipping every student? A case study of content-based flipped language classrooms. $E$ Learning and Digital Media, 14(1-2), 20-37.

Şahin A., Cavlazoglu, B., \& Zeytuncu, Y. E. (2015). Flipping a College Calculus Course: A Case Study. Educational Technology \& Society, 18 (3), 142-152.

Şengel, E. (2016). To flip or not to flip: comparative case study in higher education in Turkey. Computers in Human Behavior, 64, 547-555. 
Tütüncü, N. Aksu, M. (2018). A systematic review of flipped classroom studies in Turkish education. International Journal of Social Sciences and Education Research, 4(2), 207-229.

Tague, J., \& Baker, R. G. (2014). Flipping the classroom to address cognitive obstacles. Paper presented at Proceedings of the 121st ASEE Annual Conference, Indianapolis, IN.

Tan, C., Yue, W.G. \& Fu, Y. (2017). Effectiveness of flipped classroom in nursing education: systematic review and meta-analysis. Chinese Nursing Research, 4, 192-200.

Talbert, R., \& Valley, G. (2012). Learning MATLAB in the inverted classroom. Paper presented at Proceedings of 1119th ASEE Annual Conference \& Exposition, San Antonio, TX.

Temizyürek, F., \& Ünlü, N. A. (2015). An example of using the technology as a material in language teaching: "Flipped Classroom". Bartın University Journal of Faculty of Education, 4(1), 64-72.

Tezci, E., ve Perkmen, S. (2013). Oluşturmacı perspektiften teknolojinin öğrenme-öğretme sürecine entegrasyonu. Çağıltay, K. ve Göktaş, Y. (Ed.). Öğretim teknolojilerinin temelleri: Teoriler, araştırmalar, eğilimler (s.185-211). Ankara Turkey: PEGEM.

Tucker, B. (2012). Online instruction at home frees class time for learning. www.educationnext.org.

Tugun, V., Uzunboylu, H. \& Ozdaml, F. (2017). Coding education in a flipped classroom. TEM Journal, $6(3), 599-606$.

Tune, J.D., Sturek, M. \& Basile, D.P. (2013). Flipped classroom model improves graduate student performance in cardiovascular, respiratory, and renal physiology. Advances in Physiology Education, 37(4), $316-320$.

Turan, Z. (2015). The evaluation of flipped classroom method and examination of its effects on academic achievement, cognitive load and motivation. (doctoral dissertation). Ataturk University, Erzurum,Turkey.

Umutlu, D. (2016). Effects of different video modalities on writing achievement in flipped English classes (master' thesis). Boğaziçi University, İstanbul, Turkey.

Uzunboylu, H., \& Karagozlu, D. (2015). Flipped classroom: A review of recent literature. World Journal on Educational Technology. 7(2), 142-147.

Urfa, M. \& Durak, G. (2017). Implementation of the flipped classroom model on scientific ethics course. Journal of Education and E-Learning Research, 4(3), 108-117.

Valeo, A. (2013) Language awareness in a content-based language programme. Language Awareness, 22(2), 126-145.

Williams, B. (2013). How I flipped my classroom. NNNC Conference, Norfolk, NE.

Wilson, M., \& Gerber, L. E. (2008). How generational theory can improve teaching: Strategies for working with the 'millennials. Currents in Teaching and Learning, 1(1), 29-44.

Yavuz, M. (2016). An investigation into the effects of flipped classroom applications on the academic success and experiences of students a secondary school. (master's thesis). Atatürk University, Erzurum, Turkey.

Yildırım, F. S. \& Kiray, S. A. (2016). Flipped classroom model in education. Research Highlights in Education and Science 2016, 2.

Yılmaz, R. M. \& Baydaş, Ö. (2017). An examination of undergraduates' metacognitive strategies in preclass asynchronous activity in a flipped classroom. Education Tech Research Dev, 65, 1547-1567.

Yılmaz, Ö. (2017). Flipped higher education classroom: an application in environmental education course in primary education. Higher Education Studies, 7(3), 93-102.

Y1lmaz, R. (2017). Exploring the role of e-learning readiness on student satisfaction and motivation in flipped classrooms. Computers in Human Behavior, 70, 251-260.

Vygotsky, L. S. (1978). Mind in society: The development of higher mental process.

Zengin, Y. (2017). Investigating the use of the Khan Academy and Mathematics Software with a flipped classroom approach in mathematics teaching. Educational Technology \& Society, 20 (2), 89-100.

Zeren, M. G. (2016). The flipped geography lecture. Journal of Marmara Geography, 33, 25-57. 
Tütüncü, N. Aksu, M. (2018). A systematic review of flipped classroom studies in Turkish education. International Journal of Social Sciences and Education Research, 4(2), 207-229.

\section{Appendix 1}

Table 1. Research Studies on Flipped Classroom

\begin{tabular}{|c|c|c|c|c|c|c|}
\hline & Author, Year & Purpose & Study Design & Sam & & Major \\
\hline & & & & $\begin{array}{l}\text { Target } \\
\text { Popula- } \\
\text { tion }\end{array}$ & $\mathbf{N}$ & \\
\hline 1 & Adnan (2017) & $\begin{array}{l}\text { The impact of } \\
\text { flipped classroom } \\
\text { on academic out- } \\
\text { comes, and the } \\
\text { perceptions of } \\
\text { students compar- } \\
\text { ing to traditional } \\
\text { lecture-based } \\
\text { classroom }\end{array}$ & $\begin{array}{l}\text { Qualitative :Ac- } \\
\text { tion Research } \\
\text { Quantitative data: } \\
\text { students' grades } \\
\text { Qualitative data: } \\
\text { Open-ended } \\
\text { course survey, } \\
\text { journals, and fo- } \\
\text { cus group inter- } \\
\text { views }\end{array}$ & $\begin{array}{l}\text { Pre-ser- } \\
\text { vice sen- } \\
\text { ior Eng- } \\
\text { lish } \\
\text { teachers }\end{array}$ & $\begin{array}{l}70 \\
\mathrm{EG}=31 \\
\mathrm{CG}=39\end{array}$ & $\begin{array}{l}\text { Achievement } \\
\text { and percep- } \\
\text { tions }\end{array}$ \\
\hline 2 & $\begin{array}{l}\text { Akgün \& } \\
\text { Atıcı (2017) }\end{array}$ & $\begin{array}{l}\text { The effect of } \\
\text { flipped classroom } \\
\text { on students' } \\
\text { achievement and } \\
\text { their views }\end{array}$ & $\begin{array}{l}\text { Mixed: } \\
\text { Quantitative: pre- } \\
\text { test-posttest quasi } \\
\text { experimental de- } \\
\text { sign } \\
\text { Qualitative: semi- } \\
\text { structured inter- } \\
\text { view }\end{array}$ & $\begin{array}{l}5^{\text {th }} \text { grade } \\
\text { students }\end{array}$ & $\begin{array}{l}67 \\
\mathrm{EG}=35 \\
\mathrm{CG}=32\end{array}$ & $\begin{array}{l}\text { Achievement } \\
\text { and perspec- } \\
\text { tives }\end{array}$ \\
\hline 3 & $\begin{array}{l}\text { Aş1ksoy \& } \\
\text { Özdamlı } \\
(2016)\end{array}$ & $\begin{array}{l}\text { The effect of } \\
\text { flipped classroom } \\
\text { on the achieve- } \\
\text { ment, motivation } \\
\text { and self-suffi- } \\
\text { ciency of students } \\
\text { compared to tradi- } \\
\text { tional lecture- } \\
\text { based classrooms; } \\
\text { and students' } \\
\text { opinions about } \\
\text { flipped classroom }\end{array}$ & $\begin{array}{l}\text { Mixed: } \\
\text { Quantitative: pre- } \\
\text { test-posttest ex- } \\
\text { perimental design } \\
\text { Qualitative: semi- } \\
\text { structured inter- } \\
\text { view }\end{array}$ & $\begin{array}{l}\text { Pre-ser- } \\
\text { vice } \\
\text { sopho- } \\
\text { more } \\
\text { CEIT stu- } \\
\text { dents }\end{array}$ & $\begin{array}{l}66 \\
\mathrm{EG}=36 \\
\mathrm{CG}=30\end{array}$ & $\begin{array}{l}\text { Achievement, } \\
\text { motivation, } \\
\text { opinions, and } \\
\text { self-suffi- } \\
\text { ciency }\end{array}$ \\
\hline 4 & $\begin{array}{l}\text { Başal, A. } \\
\text { (2015) }\end{array}$ & $\begin{array}{l}\text { The perceptions } \\
\text { of students, and } \\
\text { the implementa- } \\
\text { tion of flipped } \\
\text { classroom in Eng- } \\
\text { lish language } \\
\text { teaching }\end{array}$ & $\begin{array}{l}\text { Qualitative: } \\
\text { Open-ended ques- } \\
\text { tions }\end{array}$ & $\begin{array}{l}\text { Pre-ser- } \\
\text { vice } \\
\text { teachers } \\
\text { at the De- } \\
\text { partment } \\
\text { of Eng- } \\
\text { lish Lan- } \\
\text { guage } \\
\text { Teaching }\end{array}$ & 47 & Perceptions \\
\hline 5 & $\begin{array}{l}\text { Boyraz \& } \\
\text { Ocak (2017) }\end{array}$ & $\begin{array}{l}\text { The effect of } \\
\text { flipped class- } \\
\text { room/education } \\
\text { on academic suc- } \\
\text { cess and } \\
\text { knowledge reten- } \\
\text { tion, and students' } \\
\text { opinion about this } \\
\text { approach }\end{array}$ & $\begin{array}{l}\text { Mixed: } \\
\text { Quantitative: } \\
\text { quasi-experi- } \\
\text { mental method } \\
\text { with pretest-post- } \\
\text { test control group } \\
\text { design } \\
\text { Qualitative: focus } \\
\text { group interviews }\end{array}$ & $\begin{array}{l}\text { Prepara- } \\
\text { tory class } \\
\text { students }\end{array}$ & 42 & $\begin{array}{l}\text { Achievement, } \\
\text { knowledge re- } \\
\text { tention, opin- } \\
\text { ions }\end{array}$ \\
\hline
\end{tabular}


Tütüncü, N. Aksu, M. (2018). A systematic review of flipped classroom studies in Turkish education. International Journal of Social Sciences and Education Research, 4(2), 207-229.

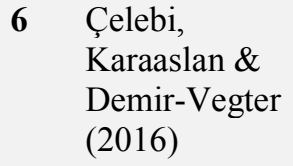

6 Çelebi,

Karaaslan \&

Demir-Vegter

(2016)

7 Çetin-

Köroğlu \&

Çakır ( 2017)
The identification

of students' views

on flipped learn-

ing

The effects of

flipped instruction

on the speaking

skills develop-

ment and learn-

ers' attitudes to-

wards flipped

classrooms

8 Çukurbaş \&

Kıyıc1 (2016)

9 Ekmekçi

(2017)

10 GöğebakanY1ld1z \&

Kiyıc1 (2016)

11 GöğebakanYıldız, Kiyıcı \& Altıntaş

(2016)

12 Görü-Doğan (2015) Ocak (2017)
To examine preservice teachers views regarding teaching activities carried out by using flipped classrooms

The impact of flipped instruction on students' writing performances compared to traditional methods, and students' attitudes towards the method

\section{The effect of flipped classroom on students'} achievement, metacognitive awareness, and epistemological beliefs To analyze the effect of flipped classroom on students' achievement and their perspectives about the model

To investigate the perspectives of students on the use of flipped classroom

To investigate effects of flipped learning on university students' achievement achievement
Mixed: Survey

Quantitative: 24-

question Likert

scale Qualitative:

open-and guided

reflection papers

Quantitative:

Quasi-experi-

mental pretest-

posttest experi-

mental design

Qualitative: case study- Openended questionnaire

Pre-ser-
vice
freshman
English
teachers

Pre-ser-

vice

freshman

English

teachers

Mixed:

Quantitative: pretest-posttest true experimental de-

sign

Qualitative: semistructured inter-

view

Quantitative: nonequivalent control group design

Prospective science teachers

66

$\mathrm{EG}=32$

$\mathrm{CG}=34$

Achievement, metacognitive awareness, and epistemological beliefs

Mixed:

Quantitative:

Achievement

Qualitative: semi-

structured inter-

view

Qualitative: Ac-
tion research

Under-

graduate

students

taking

Basic

Computer

Skills

course

Students

at the De-

partments

of Me-

chanical

\section{Achievement \\ $\mathrm{EG}=23$ and attitudes \\ $\mathrm{CG}=20$}

Quantitative: mental design
220

ME:

$\mathrm{EG}=80$

$\mathrm{CG}=80$
Achievement

$\mathrm{EG}=21$ and perspec-

$\mathrm{CG}=18$ tives
Perspectives 
Tütüncü, N. Aksu, M. (2018). A systematic review of flipped classroom studies in Turkish education. International Journal of Social Sciences and Education Research, 4(2), 207-229.

\begin{tabular}{|c|c|c|c|c|c|c|}
\hline & & & & $\begin{array}{l}\text { Engineer- } \\
\text { ing (ME) } \\
\text { and Com- } \\
\text { puter Pro- } \\
\text { gram- } \\
\text { ming } \\
(\mathrm{CP})\end{array}$ & $\begin{array}{l}\mathrm{CP}: \\
\mathrm{EG}=30 \\
\mathrm{CG}=30\end{array}$ & \\
\hline 14 & $\begin{array}{l}\text { Kocabatmaz } \\
(2016)\end{array}$ & $\begin{array}{l}\text { To investigate the } \\
\text { perspectives of } \\
\text { pre-service teach- } \\
\text { ers regarding } \\
\text { flipped classroom } \\
\text { model }\end{array}$ & $\begin{array}{l}\text { Qualitative: Case } \\
\text { study } \\
\text { Semi-structured } \\
\text { interview }\end{array}$ & $\begin{array}{l}\text { Pre-ser- } \\
\text { vice } \\
\text { teachers } \\
\text { at the De- } \\
\text { partment } \\
\text { of Eng- } \\
\text { lish Lan- } \\
\text { guage } \\
\text { Teaching }\end{array}$ & 21 & Perspectives \\
\hline 15 & Kurt (2017) & $\begin{array}{l}\text { The implementa- } \\
\text { tion and effective- } \\
\text { ness of flipped } \\
\text { classroom com- } \\
\text { paring to tradi- } \\
\text { tional lecture- } \\
\text { based classroom } \\
\text { in terms of stu- } \\
\text { dents' self-effi- } \\
\text { cacy beliefs, } \\
\text { learning out- } \\
\text { comes, and their } \\
\text { perspectives }\end{array}$ & $\begin{array}{l}\text { Mixed: Pretest- } \\
\text { Quantitative: } \\
\text { Posttest quasi ex- } \\
\text { perimental design } \\
\text { Qualitative: Focus } \\
\text { group interview }\end{array}$ & $\begin{array}{l}\text { Pre-ser- } \\
\text { vice sen- } \\
\text { ior Eng- } \\
\text { lish } \\
\text { teachers }\end{array}$ & $\begin{array}{l}62 \\
\mathrm{EG}=32 \\
\mathrm{CG}=30\end{array}$ & $\begin{array}{l}\text { Self-efficacy } \\
\text { beliefs, } \\
\text { achievement, } \\
\text { perspectives }\end{array}$ \\
\hline 16 & $\begin{array}{l}\text { Özpınar, Ay- } \\
\text { doğan-Yen- } \\
\text { mez \& Gökçe } \\
(2016)\end{array}$ & $\begin{array}{l}\text { The effect of } \\
\text { flipped classroom } \\
\text { on the academic } \\
\text { achievement and } \\
\text { motivation of the } \\
\text { students and de- } \\
\text { termination of } \\
\text { students' opinions } \\
\text { on the method }\end{array}$ & $\begin{array}{l}\text { Quantitative: } \\
\text { Quasi-experi- } \\
\text { mental method }\end{array}$ & $\begin{array}{l}\text { Sopho- } \\
\text { more stu- } \\
\text { dents at } \\
\text { Elemen- } \\
\text { tary } \\
\text { Mathe- } \\
\text { matics } \\
\text { Education } \\
\text { Program }\end{array}$ & 50 & $\begin{array}{l}\text { Achievement, } \\
\text { motivation, } \\
\text { and opinions }\end{array}$ \\
\hline 17 & $\begin{array}{l}\text { Özyurt \& } \\
\text { Özyurt (2017) }\end{array}$ & $\begin{array}{l}\text { The views of stu- } \\
\text { dents about en- } \\
\text { riching program- } \\
\text { ming and algo- } \\
\text { rithm teaching } \\
\text { with flipped class- } \\
\text { room approach }\end{array}$ & $\begin{array}{l}\text { Qualitative: } \\
\text { Semi-structured } \\
\text { interview }\end{array}$ & $\begin{array}{l}\text { Freshman } \\
\text { students } \\
\text { at the De- } \\
\text { partment } \\
\text { of Soft- } \\
\text { ware En- } \\
\text { gineering }\end{array}$ & 32 & Opinions \\
\hline 18 & Sarıgöz (2017) & $\begin{array}{l}\text { The effect of } \\
\text { flipped classroom } \\
\text { on the academic } \\
\text { success }\end{array}$ & $\begin{array}{l}\text { Quantitative: } \\
\text { Pretest-posttest } \\
\text { experimental de- } \\
\text { sign }\end{array}$ & $\begin{array}{l}\text { Pre-ser- } \\
\text { vice } \\
\text { sopho- } \\
\text { more Ele- } \\
\text { mentary } \\
\text { Teacher } \\
\text { Education } \\
\text { students }\end{array}$ & $\begin{array}{l}68 \\
E G=34 \\
C G=34\end{array}$ & Achievement \\
\hline 19 & Sezer (2016) & $\begin{array}{l}\text { The effect of the } \\
\text { application of the } \\
\text { flipped classroom } \\
\text { method on the ac- }\end{array}$ & $\begin{array}{l}\text { Mixed: } \\
\text { Quantitative: pre- } \\
\text { test-posttest ex- } \\
\text { perimental design }\end{array}$ & $\begin{array}{l}6^{\text {th }} \text { grade } \\
\text { students } \\
\text { in study- } \\
\text { ing at } 2\end{array}$ & $\begin{array}{l}68 \\
E G=35 \\
C G=33\end{array}$ & $\begin{array}{l}\text { Achievement, } \\
\text { motivation } \\
\text { and opinion }\end{array}$ \\
\hline
\end{tabular}


Tütüncü, N. Aksu, M. (2018). A systematic review of flipped classroom studies in Turkish education. International Journal of Social Sciences and Education Research, 4(2), 207-229.

\section{0 Şahin, Cavla- zoğlu. \& Zey- tuncu (2015)}

21 Şengel (2016) ademic achievement and motivation of the students; and exploring students' opinions

College students' views on flipped courses and investigate how the flipped effects their achievement in mathematics comparing to traditional classroom The effectiveness of flipped classroom approached, when coupled with problembased and cooperative learning compared to traditional classrooms; its' effects on achievement; and students' perception of the flipped classroom format

22 Tugun, Uzun- The influence of boylu \& Özdamlı (2017)

23 Urfa \& Durak (2017) flipped classroom model on digital game development and students' views on the model

To determine students' views about the use of flipped classroom

24 Yilmaz, R. (2017)

Qualitative: Structured Interview

separate

classes

Qualitative: Case study College
students

96

Achievement and views
Mixed:

Quantitative: pretest-posttest quasi experimental method

Qualitative: Survey- closed and open ended questions

Quantitative: Experimental research with pretest-posttest

\section{Mixed:}

Quantitative: descriptive statistics Qualitative: observation, interview and focus group interview Quantitative: Correlational research

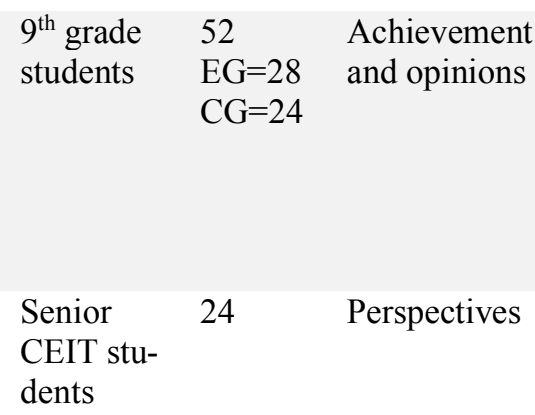

Senior

CEIT stu24

Perspectives dents

Under- $236 \quad$ Motivation
graduate
students
from the
Depart-
ments of
Science
teaching,
Social
Science
teaching
and Is-
lamic sci-
ences

The exploration of e-learning readiness on students' satisfaction and motivation in flipped classrooms

$\begin{array}{lll}\begin{array}{l}\text { Pre-ser- } \\ \text { vice }\end{array} & 96 & \begin{array}{l}\text { Achievement } \\ \text { and percep- }\end{array} \\ \begin{array}{l}\text { sopho- } \\ \text { more }\end{array} & \mathrm{CG}=55 & \begin{array}{l}\text { tion } \\ \text { CEIT stu- }\end{array} \\ \text { dents } & & \end{array}$


Tütüncü, N. Aksu, M. (2018). A systematic review of flipped classroom studies in Turkish education. International Journal of Social Sciences and Education Research, 4(2), 207-229.

\begin{tabular}{|c|c|c|c|c|c|}
\hline 25 Yilmaz, Ö. & $\begin{array}{l}\text { The usability of } \\
\text { flipped class- } \\
\text { rooms in higher } \\
\text { education: stu- } \\
\text { dents' opinions } \\
\text { and attitudes }\end{array}$ & $\begin{array}{l}\text { Mixed: } \\
\text { Quantitative: } \\
\text { posttest } \\
\text { Qualitative: focus } \\
\text { group interview }\end{array}$ & $\begin{array}{l}\text { Students } \\
\text { at Depart- } \\
\text { ment of } \\
\text { Primary } \\
\text { Education }\end{array}$ & 31 & $\begin{array}{l}\text { Opinion and } \\
\text { attitudes }\end{array}$ \\
\hline Zengin (2017) & $\begin{array}{l}\text { The effect of } \\
\text { flipped classroom } \\
\text { approach on stu- } \\
\text { dents' academic } \\
\text { achievement and } \\
\text { students' views } \\
\text { about this ap- } \\
\text { proach }\end{array}$ & $\begin{array}{l}\text { Mixed: } \\
\text { Quantitative: Sin- } \\
\text { gle group pretest- } \\
\text { posttest design } \\
\text { Qualitative: } \\
\text { Open-ended ques- } \\
\text { tionnaire }\end{array}$ & $\begin{array}{l}\text { Students } \\
\text { at Depart- } \\
\text { ment of } \\
\text { Mathe- } \\
\text { matics } \\
\text { Education }\end{array}$ & 28 & $\begin{array}{l}\text { Achievement } \\
\text { and views }\end{array}$ \\
\hline Zeren (2016) & $\begin{array}{l}\text { To examine stu- } \\
\text { dents' perceptions } \\
\text { on the benefits of } \\
\text { flipped class- } \\
\text { rooms }\end{array}$ & $\begin{array}{l}\text { Mixed: } \\
\text { Quantitative: Sur- } \\
\text { vey } \\
\text { Qualitative: Ob- } \\
\text { servation }\end{array}$ & $\begin{array}{l}\text { Students } \\
\text { at the } \\
\text { Faculty of } \\
\text { Science } \\
\text { and Liter- } \\
\text { ature }\end{array}$ & 135 & Perceptions \\
\hline
\end{tabular}

Table 2. Master's Theses and PhD Dissertations on Flipped Classroom

\begin{tabular}{|c|c|c|c|c|c|c|}
\hline & Author, Year & Purpose & Study Design & Sam & & Major \\
\hline & & & & $\begin{array}{c}\text { Target } \\
\text { Population }\end{array}$ & $\mathbf{N}$ & \\
\hline 1 & $\begin{array}{l}\text { *Alsancak \& } \\
\text { Sirakaya (2015) }\end{array}$ & $\begin{array}{l}\text { The effect of } \\
\text { flipped classroom } \\
\text { on academic } \\
\text { achievement, self- } \\
\text { directed learning } \\
\text { readiness, and } \\
\text { motivation, and } \\
\text { students' perspec- } \\
\text { tives towards the } \\
\text { method }\end{array}$ & $\begin{array}{l}\text { Mixed: } \\
\text { Quantitative: } \\
\text { Qualitative: }\end{array}$ & $\begin{array}{l}\text { Pre-service } \\
\text { senior stu- } \\
\text { dents at } \\
\text { Psychology } \\
\text { and Coun- } \\
\text { selling De- } \\
\text { partment }\end{array}$ & $\begin{array}{l}66 \\
E G=32 \\
C G=34\end{array}$ & $\begin{array}{l}\text { Achievement, } \\
\text { motivation } \\
\text { and perspec- } \\
\text { tives }\end{array}$ \\
\hline 2 & $\begin{array}{l}\text { Aydin, B. } \\
(2016)\end{array}$ & $\begin{array}{l}\text { The effect of } \\
\text { flipped classroom } \\
\text { on students' aca- } \\
\text { demic achieve- } \\
\text { ment, homework } \\
\text { stress level and } \\
\text { their transfer of } \\
\text { learning along } \\
\text { with identifying } \\
\text { students' views } \\
\text { about the method. }\end{array}$ & $\begin{array}{l}\text { Mixed: } \\
\text { Quantitative: } \\
\text { pretest-post- } \\
\text { test quasi ex- } \\
\text { perimental } \\
\text { design } \\
\text { Qualitative: } \\
\text { semi-struc- } \\
\text { tured inter- } \\
\text { view }\end{array}$ & $\begin{array}{l}\text { Pre-service } \\
\text { sophomore } \\
\text { CEIT } \\
\text { teachers }\end{array}$ & $\begin{array}{l}44 \\
E G=24 \\
C G=20\end{array}$ & $\begin{array}{l}\text { Achievement } \\
\text { and perspec- } \\
\text { tives }\end{array}$ \\
\hline 3 & $\begin{array}{l}\text { Aydin, G. } \\
(2016)\end{array}$ & $\begin{array}{l}\text { The effect of } \\
\text { flipped classroom } \\
\text { on university' stu- } \\
\text { dents' attitudes, } \\
\text { self-efficacy and } \\
\text { academic achieve- } \\
\text { ment }\end{array}$ & $\begin{array}{l}\text { Mixed: } \\
\text { Quantitative: } \\
\text { pretest-post- } \\
\text { test control } \\
\text { group true } \\
\text { experimental } \\
\text { design } \\
\text { Qualitative: } \\
\text { interview }\end{array}$ & $\begin{array}{l}\text { Pre-service } \\
\text { CEIT } \\
\text { teachers }\end{array}$ & $\begin{array}{l}33 \\
\mathrm{EG}=15 \\
\mathrm{CG}=18\end{array}$ & $\begin{array}{l}\text { Achievement } \\
\text { and attitudes }\end{array}$ \\
\hline
\end{tabular}


Tütüncü, N. Aksu, M. (2018). A systematic review of flipped classroom studies in Turkish education. International Journal of Social Sciences and Education Research, 4(2), 207-229.

\begin{tabular}{|c|c|c|c|c|c|c|}
\hline & & & $\begin{array}{l}\text { questions+ } \\
\text { individual in- } \\
\text { terviews }\end{array}$ & & & \\
\hline 4 & Ceylaner (2016) & $\begin{array}{l}\text { The effects of } \\
\text { flipped classroom } \\
\text { on students' self- } \\
\text { directed learning } \\
\text { readiness and atti- } \\
\text { tudes towards the } \\
\text { lesson }\end{array}$ & $\begin{array}{l}\text { Quantitative: } \\
\text { Quasi experi- } \\
\text { mental study }\end{array}$ & $\begin{array}{l}9^{\text {th }} \text { grade } \\
\text { students }\end{array}$ & $\begin{array}{l}46 \\
E G=23 \\
C G=23\end{array}$ & Attitudes \\
\hline 5 & Çakır (2017) & $\begin{array}{l}\text { The impact of } \\
\text { flipped classroom } \\
\text { applications on } \\
\text { students' achieve- } \\
\text { ment, cognitive } \\
\text { risk taking skills } \\
\text { and computational } \\
\text { thinking skills }\end{array}$ & $\begin{array}{l}\text { Quantitative: } \\
\text { pretest- post- } \\
\text { test quasi ex- } \\
\text { perimental } \\
\text { design }\end{array}$ & $\begin{array}{l}7^{\text {th }} \text { grade } \\
\text { students }\end{array}$ & $\begin{array}{l}53 \\
\mathrm{EG}=26 \\
\mathrm{CG}=27\end{array}$ & Achievement \\
\hline 6 & $\begin{array}{l}\text { Çalışkan, N. } \\
\text { (2016) }\end{array}$ & $\begin{array}{l}\text { The influences of } \\
\text { flipped classroom } \\
\text { on students' } \\
\text { learning, and their } \\
\text { perspectives on } \\
\text { the flipped class- } \\
\text { room }\end{array}$ & $\begin{array}{l}\text { Mixed: } \\
\text { Quantitative: } \\
\text { pretest-post- } \\
\text { test design } \\
\text { Qualitative: } \\
\text { observational } \\
\text { field notes, } \\
\text { focus group } \\
\text { interviews, } \\
\text { semi-struc- } \\
\text { tured inter- } \\
\text { views }\end{array}$ & $\begin{array}{l}\text { Preparatory } \\
\text { class stu- } \\
\text { dents }\end{array}$ & 22 & $\begin{array}{l}\text { Achievement } \\
\text { and perspec- } \\
\text { tives }\end{array}$ \\
\hline 7 & Güç (2017) & $\begin{array}{l}\text { The effect of } \\
\text { flipped classroom } \\
\text { on students' aca- } \\
\text { demic achieve- } \\
\text { ment ad their atti- } \\
\text { tudes towards the } \\
\text { course; and stu- } \\
\text { dents' opinions } \\
\text { about the method }\end{array}$ & $\begin{array}{l}\text { Mixed: } \\
\text { Quantitative: } \\
\text { quasi-experi- } \\
\text { mental pre- } \\
\text { test-posttest } \\
\text { experimental } \\
\text { design } \\
\text { Qualitative: } \\
\text { semi-struc- } \\
\text { tured inter- } \\
\text { view }\end{array}$ & $7^{\text {th }}$ grade & & $\begin{array}{l}\text { Achievement, } \\
\text { attitudes and } \\
\text { opinions }\end{array}$ \\
\hline 8 & Sağlam (2016) & $\begin{array}{l}\text { The effect of } \\
\text { flipped classroom } \\
\text { on students' } \\
\text { achievement and } \\
\text { their attitudes to- } \\
\text { wards the method }\end{array}$ & $\begin{array}{l}\text { Quantitative: } \\
\text { non-equiva- } \\
\text { lent pretest- } \\
\text { posttest ex- } \\
\text { perimental } \\
\text { design }\end{array}$ & $\begin{array}{l}\text { Preparatory } \\
\text { class stu- } \\
\text { dents }\end{array}$ & $\begin{array}{l}56 \\
E G=29 \\
C G=27\end{array}$ & $\begin{array}{l}\text { Achievement } \\
\text { and attitudes }\end{array}$ \\
\hline 9 & * Turan (2015) & $\begin{array}{l}\text { The impact of } \\
\text { flipped class- } \\
\text { rooms on stu- } \\
\text { dents' achieve- } \\
\text { ment, cognitive } \\
\text { load and motiva- } \\
\text { tion; and students' } \\
\text { perspectives about }\end{array}$ & $\begin{array}{l}\text { Mixed: } \\
\text { Quantitative: } \\
\text { quasi-experi- } \\
\text { mental de- } \\
\text { sign } \\
\text { Qualitative: } \\
\text { student view } \\
\text { questionnaire } \\
\text { and semi- }\end{array}$ & $\begin{array}{l}\text { Pre-service } \\
\text { teachers at } \\
\text { Early } \\
\text { Childhood } \\
\text { Education } \\
\text { Depart- } \\
\text { ment }\end{array}$ & $\begin{array}{l}116 \\
E G=58 \\
C G=58\end{array}$ & $\begin{array}{l}\text { Achievement, } \\
\text { motivation } \\
\text { and perspec- } \\
\text { tives }\end{array}$ \\
\hline
\end{tabular}


Tütüncü, N. Aksu, M. (2018). A systematic review of flipped classroom studies in Turkish education. International Journal of Social Sciences and Education Research, 4(2), 207-229.

$\begin{array}{ll}\text { flipped class- } & \text { structured in- } \\ \text { rooms } & \text { terview }\end{array}$

10 Umutlu (2016)

\begin{tabular}{|c|c|c|c|}
\hline $\begin{array}{l}\text { The effect of } \\
\text { flipped classroom } \\
\text { on students' writ- } \\
\text { ing achievement } \\
\text { in an English } \\
\text { course, and the in- } \\
\text { terplay effects of } \\
\text { students' learning }\end{array}$ & $\begin{array}{l}\text { Quantitative: } \\
\text { quasi-experi- } \\
\text { mental pre- } \\
\text { test-posttest } \\
\text { design }\end{array}$ & $\begin{array}{l}\text { Preparatory } \\
\text { class stu- } \\
\text { dents }\end{array}$ & $\begin{array}{l}127 \\
E G=15 \\
E G=18 \\
E G=20 \\
E G=27 \\
E G=21 \\
E G=17 \\
C G=18\end{array}$ \\
\hline
\end{tabular}

styles, autonomy levels, and critical thinking disposition levels

11 Yavuz (2016)

The effect of

Mixed: $\quad 10^{\text {th }}$ grade

flipped classroom on students' success and their

Quantitative: pretest-posttest experi-

feedback regarding its application mental design Qualitative: focus group interview

\section{7}

students

$\mathrm{EG}=13$

$\mathrm{CG}=14$

Achievement and perspectives
Achievement

$G=20$

$\mathrm{H}=27$

$\mathrm{G}=17$

$\mathrm{G}=18$

$*=\mathrm{PhD}$ Dissertation

$\mathrm{EG}=$ Experimental Group

$\mathrm{CG}=$ Control Group 